\author{
Mateusz Podlecki \\ Uniwersytet im. Adama Mickiewicza w Poznaniu \\ Instytut Filologii Polskiej \\ ORCID: 0000-0002-5728-9525
}

\title{
Schemat składniowy jako idiom - prolegomena do frazeologii operacyjnej
}

\begin{abstract}
A b st rakt: Celem artykułu jest wstępna charakterystyka frazeologii operacyjnej, której kształt wyłania się z gramatyki operacyjnej Andrzeja Bogusławskiego. Rozważania w pierwszym podrozdziale szkicu - osadzone na gruncie amerykańskiej filozofii neopragmatystycznej - dotyczą statusu ontologicznego idiomów. Dwie następne partie tekstu są poświęcone, kolejno, terminom: schemat syntaktyczny oraz frazeologizm aktualny. Drugie ze wskazanych wyrażeń oznacza realizację tekstową związku frazeologicznego, tzn. elementu sfery langue. W ostatniej części artykułu autor określa (z proporcjonalistycznego punktu widzenia) właściwy przedmiot badań omawianego paradygmatu frazeologii teoretycznej - jest to byt językowy (frazeologizm, dokładniej: matryca frazeotwórcza) objawiający nieregularność już na poziomie schematu syntaktycznego i/lub na płaszczyźnie suprasegmentalnej.
\end{abstract}

Słowa klucze: frazeologia operacyjna; gramatyka operacyjna; matryca frazeotwórcza; jednostka języka

\section{Wprowadzenie}

Jeżeli nie przyjmie się określonych przesłanek teoretycznych, to przecząca lub twierdząca odpowiedź na pytanie: czy wyrażenie x y jest związkiem frazeologicznym? nie może być - posługując się terminologią Iana Hackinga - „kandydatem do wartości logicznej” (za: Rorty 1996: 38), co znaczy, że 
odpowiedziom „nie” i „tak” nie sposób przypisać wartości prawdy lub fałszu. Zgodnie z ustaleniami Andrzeja Marii Lewickiego klasy faktów językowych - w tym: klasa frazeologizmów - „nie istnieją przed wyodrębniającymi je pracami językoznawczymi” (Lewicki 2003: 14). Podobną tezę wysunął Wojciech Chlebda, według którego o tym, czy element $x y$ jest związkiem frazeologicznym, decydują kryteria frazeologiczności, opracowane i/lub przyjęte przez lingwistę (Chlebda 2003: 39). Wypowiedzi obu badaczy są zbieżne z konstruktywistyczną teorią interpretacji Stanleya Fisha ${ }^{1}$. U jej podstaw legły m.in. następujące założenia: i) interpretacja to nie sztuka objaśniania, ale konstruowania czegoś (tutaj: pojęcia frazeologizmu), ii) wszystkie przedmioty (tutaj: przedmiot zainteresowania frazeologii) tworzy się - a nie odkrywa - dzięki odpowiednim strategiom interpretacyjnym, iii) akt rozpoznania czegoś jako czegoś (tutaj: danego bytu językowego jako frazeologizmu) jest raczej źródłem cech formalnych oraz pozostałych właściwości tego, co zostało rozpoznane jako $\cos ^{2}$ (Fish 2002, zwłaszcza: 85-86; 95-96).

Odmienne stanowisko zajmuje Beata Jezierska, która twierdzi, że idiomy funkcjonują w obiegu komunikacyjnym niezależnie od teorii frazeologicznych i że tego typu składniki planu langue wyodrębnia się nawet intuicyjnie (Jezierska 2016: 47-52). Badaczka używa terminu intuicja, ale go nie operacjonalizuje (w przeciwieństwie do generatywistów). Tok rozumowania lingwistki zrekonstruuję za pomocą instrumentów stworzonych na gruncie hermeneutycznej koncepcji interpretacji transakcyjnej (Januszkiewicz 2012, 2013). Z tej perspektywy podmiot poznający w c zy tuj e się w tekst, tzn. w potoku mownym dostrzega ciąg znaków odznaczający się jakąś nieregularnością, a następnie wc zytuje ów fragment we własny horyzont poznawczy (por. Januszkiewicz 2012: 76-77; 2013: 228), tzn. na podstawie swojej

1 Po raz pierwszy koncepcja amerykańskiego neopragmatysty została wykorzystana w polskich badaniach frazeologicznych najprawdopodobniej przez Krzysztofa Skibskiego (Skibski 2017: 161-205).

${ }^{2}$ Na przykład autorzy SFWP (SFWP: 820) zarejestrowali związek frazeologiczny mówić, pleść, gadać co ślina na język przyniesie. Iwona Kosek z kolei - posługując się narzędziami wypracowanymi przez Andrzeja Bogusławskiego - w alternatywny sposób wyznaczyła granicę tej jednostki leksykalnej:_co komu ślina na język przyniesie (Kosek 2011: 17). Rozpoznanie przez olsztyńską językoznawczynię czasowników mówić, pleść i gadać jako reprezentantów klasy substytucyjnej niezamkniętej i uznanie niniejszego kryterium za relewantne spowodowało, że w tej interpretacji omawiane spetryfikowane połączenie wyrazowe odznacza się innym kształtem formalnym niż w SFWP. 
intuicji, czyli - najprawdopodobniej - zinterioryzowanych, p o t o c z n y ch, niedostatecznie w y raźn y ch sądów na temat języka, uznaje wyróżniony obiekt za związek frazeologiczny, dokładniej: za jego tekstową aktualizację (por. rozróżnienie wiedzy jasnej i wyraźnej w: Zawadowski 1966: 8-10; potoczność rozumiem w sensie epistemologicznym, por. Bańko 2001: 62-77). Innymi słowy, Beata Jezierska de facto czyni z intuicji nieostre kryterium delimitacji idiomatycznych wielkości językowych. Zgłaszany zaś przez autorkę postulat dotyczący uprzedniości ontologicznej frazeologizmów (uprzedniości wobec teorii frazeologicznych, które mają być powołane do o dtwa rzania kształtu ustabilizowanych związków wyrazowych) jest wątpliwy metodologicznie, bowiem implikuje twierdzenie, że koncepcje językoznawcze winny odkrywać - tutaj: w rozumieniu Saula Kripkego - r z e c z y w i stą naturę tego, co - bez przyjęcia odpowiednich przesłanek - rze czyw istej natury mieć nie może (za: Rorty 1999: 131). Na zewnątrz ${ }^{3}$, tj. w języku, do którego struktury czy też systemu nie mamy bezpośredniego dostępu (Bobrowski 2005: 41-44), nie istnieje kryterium abstrahujące od lingwistycznych paradygmatów i rozstrzygające o tym, czym jest idiom, tzn. jaki zbiór cech go tworzy. Na przykład we frazematyce - z powodu uznania za konstytutywne kryterium reprodukcji formy językowej dla zwerbalizowania określonej wiązki sensów (Chlebda 2003) - przysłowie każda pliszka swój ogonek chwali jest związkiem frazeologicznym, natomiast w proporcjonalistycznym podejściu do języka paremia ta traci swój jednostkowy status, ponieważ stanowi zdanie zamknięte w sensie logicznym, tzn. nie spełnia warunku bycia funktorem, aktualizowanym za każdym razem w trakcie zdarzenia komunikacyjnego (Bogusławski 1989: 20, 24-25). Jeśli przyjmie się diagnozę poznawczą Ireneusza Bobrowskiego, zgodnie z którą lingwiści budują m o dele systemu językowego (a więc nie odwzorowują w swoich opisach rzeczywistego systemu!), to nie można orzec, że któraś z propozycji teoretycznych: Wojciecha Chlebdy lub Andrzeja Bogusławskiego trafnie - w znaczeniu: veritas est adaequatio rei et intellectus - zdaje sprawę z istoty związku frazeologicznego i z wewnętrznej organizacji sfery langue (Bobrowski 2005: 41-44). Stwierdzenie, że np. przysłowia współtworzą zbiór idiomatycznych jednostek leksykalnych, z czego wynika, iż należą one do składników rzeczywistego systemu, jest nierozstrzygalne pod względem

\footnotetext{
3 Por. użycie tego wyrażenia w: Rorty 1996: 107-134.
} 
prawdziwościowym (por. Bobrowski 2005: 43). Problem ów można rozwiązać wyłącznie w obrębie danego modelu systemu językowego, będącego projekcją wiedzy wyraźnej uczonego. Przekonanie o tym, iż koncepcje naukowe nie przedstawiają adekwatnie (trafnie) lub nieadekwatnie rzeczywistości, wyraził najpełniej Donald Davidson (Davidson 2005: 87-167). Uznając stanowisko filozofa za słuszne, nadaję w niniejszym szkicu obowiązującą moc antyreprezentacjonistycznej myśli dobitnie zwerbalizowanej przez Richarda Rorty'ego: prawdy oraz fakty (a więc i klasy faktów językowych) się stwarza, a nie odkrywa (Rorty 1996: 19-43). Sankcjonuje ona również konstatację, że jednostki języka (w tym: frazeologizmy) nie są dane ani z góry, ani bezpośrednio (Bogusławski 1993: 61-62; 1996: 47-48).

Na potencjalny zarzut mieszania porządków: ontologicznego i epistemologicznego odpowiem następująco: w języku obiektywnie, tzn. niezależnie od aktywności uczonych, istnieją elementy nieregularne pod jakimś względem, dostatecznie doniosłe właśnie z powodu tej nietypowości (Bogusławski 1989: 24), objawiające ją m.in. podczas praktyki uczenia się języków obcych (należy przecież opanować pamięciowo kształt - przykładowo - wielokomponentowych wyrażeń semantycznie asumarycznych, por. Jezierska 2016: 50-51). O tym, jak p r e c y z y j n i e wyznaczać granicę obiektów nieregularnych, tzn. jak określać ich tożsamość, decydują jednak lingwiści na podstawie przyjętych założeń ${ }^{4}$. Postulowany ostateczny kształt tego typu elementów zależy więc od rezultatu interpretacji podjętej przez badacza w ramach danego paradygmatu. Poznanie stwarza byt lingwalny w tym sensie, że językoznawca - postępując według odpowiednich procedur - ustala formę analizowanego wyrażenia i uznaje ją za obowiązującą, istniejącą obiektywnie lub - w wersji mniej ortodoksyjnej - intersubiektywnie (w konkurencyjnych teoriach oraz w języku, do którego - powtórzę - nie mamy bezpośredniego wglądu, wyrażenie to może mieć inny kształt). Język stanowi tutaj jedynie przyczynowy określnik interpretacji lingwisty (por. uwagi na temat Rortiańskiej epistemologii w: Szahaj 2012: 19-29).

${ }^{4}$ Kontrowersje dotyczą nie tylko frazeologii. Ze względu na objętość artykułu ograniczę się do następującej ilustracji: Zygmunt Saloni i Marek Świdziński doszli do wniosku, iż w zdaniu $O$ to, czy na swoich głosować, chodziło kształt chodzi konotuje frazę rozpoczynającą się od przyimka $o$. Magdalena Danielewiczowa wykazała natomiast, iż chodzi o jest niepodzielną jednostką leksykalną, ergo: składnik o nie jest konotowany (Saloni, Świdziński 2001: 299; Danielewiczowa 2010: 20-22). Por. także przypis 2. 
Frazeologiczny (szerzej: systemowy) status tak pojmowanych nieregularnych obiektów językowych jest również determinowany przez przyjęte konwencje naukowe. Na przykład fraza nie chce mi się z toba gadać może zostać uznana m.in. za: skrzydlate słowo, a więc frazeologizm (Chlebda 2005, 2010; Fliciński 2008; WSF: 152); skrzydlate słowo, a więc nie frazeologizm (Шулежкова 2002; Liberek 1999; Lewicki 2003: 302), semantyczno-składniową kompozycję, a więc nie frazeologizm (Bogusławski 2008: 57-58). Przyjmuję zatem, że pojęcie związku frazeologicznego wymaga obligatoryjnego zrelatywizowania do którejś z teorii lingwistycznych - to w ich obrębie konstruuje się model systemu językowego i ustala zespół cech konstytuujących idiom. Oznacza to, iż - zgodnie z rozpoznaniem Andrzeja Marii Lewickiego - frazeologizmy są powoływane do życia w pracach językoznawczych. Konkluzja brzmi więc następująco: dostrzeżony przez badacza element języka, który odznacza się nieregularnością, jest tylko elementem języka odznaczającym się nieregularnością, dopóki nie zostanie okazane, iż zasłużył na miano związku frazeologicznego (Bogusławski 1989: 27).

\section{Ustalenia terminologiczne}

Związek frazeologiczny pojmuję za Andrzejem Bogusławskim jako nietypową jednostkę języka (Bogusławski 1989: 18-20). Termin jednostka języ$k a$ oznacza zaś niepodzielny bilateralny byt językowy, który wyodrębnia się w układach proporcjonalnych, stanowi właściwy nośnik sensu i który jest dwustronnie formalnie oraz funkcjonalnie rozłączny z innymi elementami w klasach niezamkniętych, tzn. klasach o charakterystyce ogólnej (Bogusławski: 1976, 1987, 1988, 1989, 1996, 2008). Zbiór jednostek języka dzieli się na: KSS-y, czyli elementy zawierające co najmniej jeden konstrastywny segment sylabiczny, oraz operacje (jednostki operacyjne), tzn. elementy niemające tego typu segmentów (Bogusławski 1988)5. Grupę KSS-ów współtworzy m.in. frazeologizm docent marcowy 'osoba mianowana na stanowisko docenta mimo braku habilitacji’ (PJZ: 107), a zasób operacji zasilają np. jednostki: $\cos ^{-}{ }_{i}$ czegoś- ${ }_{j}$ 'j łudząco podobne do $i$ ', aktualizowana w tekstach m.in. pod postacią wyrażeń: perły zębów, puste oczodoły półek (PJZ: 477),

5 Sebastian Żurowski nazywa operacje nieleksykalnymi jednostkami języka (Żurowski 2013). 
czy też co_, to_ 'mówiący wskazuje, że stan rzeczy, o którym mowa, mimo wiadomych niedogodności niesie określoną korzyść', generująca np. ciągi Nacierpiała się, nagłodowała, ale co schudła, to schudta (SRiPP: 220-221). W skład drugiej operacji wchodzą wykładniki segmentalne co i to, ale w wypowiedzi charakteryzującej się fregowską powagą nie mogą one wystąpić pod przyciskiem kontrastywnym, dlatego jednostka ta została zakwalifikowana do zbioru jednostek operacyjnych. Operacje stanowią główny przedmiot zainteresowania frazeologii operacyjnej, której podstawy teoretyczne zarysuję w części IV pt. Założenia frazeologii operacyjnej, czyli podsumowanie. W opracowaniach rejestrujących nieleksykalne jednostki języka zapisuje się je w formie schematów syntaktycznych: „tradycyjnych” (por. kształt dwu przywołanych operacji) i piętrowych ${ }^{6}$. Terminem schemat syntaktyczny nie posługuję się jednak w znaczeniu nadanym mu w badaniach nad składnią polszczyzny. Nie mam na myśli uogólnionej, abstrakcyjnej postaci zdania empirycznego, poddającej się formalizacji typu: $V_{\text {niefl }}-$ Sent czy $V v P$ (Inf) INFP ADVP (Grzegorczykowa 2012: 49-51, 55-58; Saloni, Świdziński 2001: 291-301). Schemat syntaktyczny to - tutaj - jednostka języka w postaci układu pozycji składniowych (niektóre z nich jeszcze przed użyciem w akcie mowy są wypełnione materiałem słownym, np. czasownikiem), wymagających podczas zdarzenia komunikacyjnego uzupełnienia elementami leksykalnymi w odpowiedniej formie gramatycznej, odznaczającymi się ściśle określonymi właściwościami kategorialno-morfologicznymi. Taki schemat - jak wskazuje Magdalena Danielewiczowa - jest reprezentowany w tekstach przez zamknięte klasy wyrażeń, tzn. na pozycje składniowe układu wchodzą frazy, które nie mogą być dowolnie rozbudowywane, por. sytuację przeciwną - oto fraza podmiotowa rzeczownikowa przy czasowniku czynnościowym, odznaczająca się potencją rekurencyjnego rozwijania w nieskończoność, ograniczonego tylko czynnikami zewnętrznojęzykowymi: ,Janek; kolega Janek; nasz kolega Janek; nasz dobry kolega Janek; nasz dobry, miły, ale trochę leniwy kolega Janek..." (Danielewiczowa 2010: 23-24). Pod-

6 Por. zapis:

$i^{\circ}$

$-\bar{i}_{-}{ }^{\circ}{ }^{\circ}$

'zwrot wyrażający zapewnienie o wiadomej rzeczy jako o czymś oczywistym'.

Jednostki tej używa się do produkcji m.in. następujących wypowiedzeń: przyjdzie, przyjdzie (VPA: 347). 
sumowując, w niniejszym ujęciu termin schemat syntaktyczny obejmuje swoim zakresem wielkości językowe rzędu: schematów konotacyjnych, np. ktoś oszukat/naciąt kogoś na ileś (Danielewiczowa 2010: 23), operacji (por. egzemplifikacje na s. 183-184) czy też jednostek typu ja komuś ${ }_{\mathrm{i}}$ po-Przykładowe realizacje tekstowe ostatniego schematu prezentują się następująco: ja ci pokrzyczę; ja ci pośpiewam; ja jej powagaruję (Bogusławski 1989: 19; PJZ: 152; Danielewiczowa 2010: 12).

Tak pojmowane schematy syntaktyczne mogą być nośnikiem wartości semantycznej. Znaczenie jednostki językowej rozumiem jako „ściśle określony zbiór konsekwencji (następstw), jakie wynikają z jej użycia" (Nowak 2013: 67). Innymi słowy, znaczeniem jednostki $x y$ jest to, co za jej pomocą zostało lub może zostać powiedziane wprost, tzn. to, czego odbiorca dowiedział się lub może się dowiedzieć na podstawie tego, że nadawca użył lub użyje jednostki $x y$ w sposób bezpośredni (Grochowski 1982: 46; 1993: 48; Bednarek, Grochowski 1993: 9-10).

\section{Inwariant semantyczno-strukturalny jako związek frazeologiczny}

W schematach konotacyjnych, które nie charakteryzują się nieregularnością pod jakimkolwiek względem, właściwy sens jednostki zawiera się w członie fundującym strukturę powierzchniową ${ }^{7}$ W schemacie ktoś odwiedził kogoś pozycje markowane zaimkami: ktoś i kogoś wskazują, iż czasownik odwiedzić wymaga podrzędników u z u p e łn i a ją c y c h semantycznie treść verbum (mowa o frazach nominalnych odsyłających do agensa i obiektu, por. Grzegorczykowa 2012: 49-53). Z odmienną sytuacją mamy do czynienia wtedy, gdy głównym nośnikiem znaczenia jest schemat syntaktyczny - z wykładnikami segmentalnymi lub bez nich (por. przywoływane w tym szkicu przykłady z PJZ, VPA i SRiPP, s. 183-185). Struktura może być formalnie konstytuowana np. przez czasownik dwumiejscowy, ale właściwy sens tkwi nie w komponencie werbalnym, lecz w całostce, której ów człon leksykalny jest składnikiem. Poniższa tabela prezentuje dziewięć schematów syntaktycznych wyposażonych - według autorów - w konwencjonalne znaczenia

7 Terminów sens i znaczenie używam wymiennie (rezygnuję z rozróżnienia tych pojęć wprowadzonego w: Frege 1977: 60-88). 
(półpauzy w komórkach oznaczają, że lingwistki zrezygnowały z eksplikowania sensu wyrażeń za pomocą syntetycznych definicji).

Tabela 1. Schemat syntaktyczny jako nośnik wartości semantycznej

\begin{tabular}{|c|c|c|c|c|}
\hline Lp. & $\begin{array}{c}\text { Adres } \\
\text { bibliograficzny }\end{array}$ & $\begin{array}{c}\text { Postulowany } \\
\text { ksztalt schematu }\end{array}$ & Znaczenie & $\begin{array}{c}\text { Przyklad } \\
\text { realizacji tekstowej }\end{array}$ \\
\hline 1. & Stefanowitsch 2007 & $W a W a$ & $\begin{array}{l}\text { 'Emphase/Intensi- } \\
\text { vierung' }\end{array}$ & $\begin{array}{l}\text {...many, many } \\
\text { things to do }\end{array}$ \\
\hline 2. & Rosalska 2011 & ${ }_{-} p o_{-}$ & - & $\begin{array}{c}\text {...nagrywał } \\
\text { zdanie po zdaniu }\end{array}$ \\
\hline 3. & Żabowska 2017 & $-a_{-i}$ & $\begin{array}{l}\text { 'mówię o wypo- } \\
\text { wiedzi W'" takiej, } \\
\text { że i) jest w niej po- } \\
\text { wiedziane, który } x \text {; } \\
\text { nie mówię, który } x \text {, } \\
\text { bo dla tego, o czym } \\
\text { mówię, nie ma } \\
\text { znaczenia, który } x \\
\text { zostanie wskazany' }\end{array}$ & $\begin{array}{c}\text { ten a ten } \\
\text { [np. mężczyzna] }\end{array}$ \\
\hline 4. & $\begin{array}{l}\text { Chlebda 2005: } \\
\text { 253-263 }\end{array}$ & $\begin{array}{c}\text { (nie) coś (jest/nie } \\
\text { jest) dla kogoś/ } \\
\text { czegoś }\end{array}$ & $\begin{array}{l}\text { ‘istnienie / brak } \\
\text { sprzyjających } \\
\text { warunków } \\
\text { dla (za)istnienia } \\
\text { kogoś/czegoś’ }\end{array}$ & $\begin{array}{c}\text { pogoda } \\
\text { dla kinomanów }\end{array}$ \\
\hline 5. & $\begin{array}{c}\text { Wierzbicka 1987, } \\
\text { zwłaszcza: } 107-110\end{array}$ & $\begin{array}{c}(A R T) N \text { is }(A R T) \\
N\end{array}$ & $\begin{array}{l}\text { 'tautologies of } \\
\text { obligation' }\end{array}$ & .... a deal is a deal \\
\hline 6. & $\begin{array}{l}\text { Kopczyńska 2002, } \\
\text { zwłaszcza: } 36-37\end{array}$ & $X$ dla ubogich & $\begin{array}{c}\text { 'w gorszym ga- } \\
\text { tunku, na niskim } \\
\text { poziomie, słaby, } \\
\text { marny'* }\end{array}$ & $\begin{array}{l}\text { Schawrzenegger } \\
\text { dla ubogich }\end{array}$ \\
\hline 7. & Skorupka 1967: 189 & drugi $_{-}$ & 'taki sam jak' & drugi ojciec \\
\hline 8. & $\begin{array}{l}\text { Dziamska-Lenart, } \\
\text { Fliciński 2016, } \\
\text { zwłaszcza: } 20-24\end{array}$ & $\begin{array}{c}\text { rewolucja }+ \\
\text { jakaś }\end{array}$ & $\begin{array}{c}\text { 'gwałtowne, często } \\
\text { niekontrolowane } \\
\text { zmiany w jakiejś } \\
\text { dziedzinie' }\end{array}$ & $\begin{array}{l}\text { rewolucja } \\
\text { seksualna }\end{array}$ \\
\hline 9. & $\begin{array}{c}\text { Szerszunowicz, } \\
\text { Vidović Bolt 2019, } \\
\text { zwłaszcza: } 289-291\end{array}$ & $\begin{array}{c}\text { perta }+ \text { TOPO- } \\
\text { NIM }_{G E N}\end{array}$ & - & perła Bałtyku \\
\hline
\end{tabular}

* Autorka przejmuje definicję za: SPP: 271.

Źródło: opracowanie własne. 
Każdy ze zrekonstruowanych schematów ma być - zgodnie z ustaleniami przywołanych badaczy - elementem systemu językowego. Autorzy wskazanych prac deklarują, iż wyodrębnione przez nich struktury są: jednostkami języka (ciągi: 2. i 3.), frazeologizmami (wyrażenia: 6. i 7.), frazemem (kształt: 4.), tzn. jednostką języka w rozumieniu Wojciecha Chlebdy, nie: Andrzeja Bogusławskiego (Chlebda 2005: 160), modelami potencjalnie frazemotwórczymi (schematy: 8. i 9.), układami, w których zakodowano znaczenie uznawane za arbitralne (wzory repetycyjne: 1. i 5.). Z proporcjonalistycznego punktu widzenia do zbioru jednostek języka w postaci struktur składniowych będących - jako całość - nośnikiem znaczenia leksykalnego kwalifikują się ciągi: 2., 3. i 4. (w ostatnim wypadku musi zostać dowiedzione, że prymarną funkcją frazemu nie jest odsyłanie do eptonimu pogoda dla bogaczy, który utrwalił w polszczyźnie opisywany przez Wojciecha Chlebdę inwariant). W przykładach: 6., 7., 8. i 9. właściwy sens mieści się w wyrażeniach-metaforach: dla ubogich, drugi, rewolucja oraz perła (taką interpretację przyjęto m.in. w WSJP PAN). Oznacza to, iż omawiane schematy mają taki kształt formalny, jaki zaprezentowano w tabeli, ale zmienne: $X_{-}$, jakaś i TOPONIM ${ }_{\text {GEN }}$ nie pełnią już funkcji znaczenionośnej - wskazują one ,jedynie” na właściwości składniowe: frazy przyimkowej, przymiotnika i rzeczowników oraz zapowiadają wystąpienie w tekście określeń mających u zupełnić semantycznie treść leksemów. W tym świetle np. perła Bałtyku jest regularną konstrukcją syntaktyczną. Taką konstrukcją będzie również sformułowanie ...a deal is a deal, jeśli uzna się za obowiązującą metaepistemiczną interpretację funktora to be_, tzn. jeżeli przyjmie się, iż sens 'o czymś wiadomo coś oczywistego' jest zawarty w czasowniku, a nie w układzie quasi-tautologicznym opatrzonym numerem 5. (to rozwiązanie zaproponował Adam Dobaczewski w: Dobaczewski 2018: 141-169). Toruński językoznawca wykazał również, że schemat 1. nie może być jednostką języka, ponieważ generowane przez niego asyndetyczne szeregi repetycyjne są motywowane ikonicznie, co prowadzi do wniosku, iż u podstaw struktury 1. nie mogło lec arbitralne znaczenie (Dobaczewski 2018: 56-70).

Dorota Kopczyńska i Joanna Szerszunowicz twierdzą, że schematy tego typu, tzn. struktury, którym w systemie językowym przypisano - jako niepodzielnym całościom - określone znaczenie, sytuują się na pograniczu składni i frazeologii (Kopczyńska 2002; Szerszunowicz 2012). We frazeologii operacyjnej takie jednostki języka określa się jednoznacznie mianem związków 
frazeologicznych. Czyni się tak z powodu niety pow ości schematów, przejawiającej się w tym, że funkcja pozycji składniowych współtworzących struktury polega i na sygnalizowaniu właściwości gramatycznych, i na niesieniu właściwego sensu.

Owo podejście harmonizuje z tradycją: przekonanie, że inwariantem związku frazeologicznego może być schemat syntaktyczny obdarzony znaczeniem sygnifikatywnym, wyrazili - jako pierwsi w polskiej refleksji frazeologicznej - Andrzej Maria Lewicki oraz Anna Pajdzińska (Lewicki 1976; 2003: 9-152; Pajdzińska 1982). Według Walerija Mokijenki inwariant semantyczno-strukturalny jest - wbrew temu, co się powszechnie sądzi - historycznie zmienny (Мокиенко 1980: 13). Realizacje tekstowe inwariantu wpływają na jego kształt (np. wyprodukowane przez schemat składniowy ciągi zbudowane z komponentów ekspresywnych mogą ukonstytuować i - następnie utrwalać nacechowanie ekspresywne neutralnej dotychczas struktury).

Status realizacji tekstowych inwariantów jest interesujący poznawczo ${ }^{8}$. Przykładowe syntagmy znajdujące się w ostatniej kolumnie zestawienia należą - według poszczególnych badaczy - do zbioru: konstrukcji syntaktycznych (wyrażenie: 2.) $)^{9}$, frazeologizmów (połączenia: 6. i 7.), frazemów aktualnych (ciąg: 4.), reproduktów, tzn. frazemów (kształty: 8. i 9.). Termin konstrukcja syntaktyczna implikuje twierdzenie, iż realizacja tekstowa $z d a-$ nie po zdaniu jest rezultatem swobodnego łączenia składników leksykalnych, tymczasem generowanie takich wyrażeń polega na nieswobodnym, tzn. obwarowanym ograniczeniami systemowymi, uzupełnianiu pozycji składniowych schematu elementami z osi paradygmatycznej. Ograniczenia te polegają m.in. na obowiązkowym wystąpieniu w sąsiedztwie przyimka różnych form gramatycznych tego samego leksemu - reduplikowany wyraz musi być przedstawicielem określonej klasy substytucyjnej niezamkniętej. Produkt operacji jest - obligatoryjnie - frazą dwutaktową z akcentem fra-

${ }^{8} \mathrm{~W}$ niniejszym passusie zajmują mnie inwarianty zamieszczone w tabeli. Ich kształt nie musi być - jak już wykazałem - tożsamy z kształtem inwariantów (re)konstruowanych w perspektywie proporcjonalistycznej. Jeżeli w głównej części tekstu nie pojawi się któryś przykład z tabeli, to znaczy, że autorzy nie zarezerwowali specjalnej nazwy dla aktualizacji tekstowych inwariantnych schematów.

9 Wypada zaznaczyć, że w głównej części swojego artykułu Paulina Rosalska określiła wyrażenia generowane przez jednostkę _ po _ jako konstrukcje syntaktyczne (Rosalska 2011: 154-155). Z kolei w podsumowaniu badaczka nazwała realizacje wskazanej jednostki „wynikiem działania operacji iterujących” (Rosalska 2011: 160). 
zowym na drugim takcie (por. SRiPP, s. 245-246). Uważam więc, że termin konstrukcja syntaktyczna nie wydaje się adekwatną nazwą dla tekstowych realizacji jednostki języka odnotowanej przez Paulinę Rosalską (argumenty, które przytoczyłem w niniejszym akapicie, przemawiają za tym, by inwariant oraz jego aktualizacje traktować jako byty z zakresu frazeologii, a nie: z pogranicza składni i frazeologii).

Stanisław Skorupka oraz Dorota Kopczyńska doszli do wniosku, że połączenia produkowane przez frazeologizmy w postaci schematów syntaktycznych są związkami frazeologicznymi (przykłady: 6. i 7.). Takie rozwiązanie nie zdaje sprawy z różnicy pomiędzy idiomem (jako składnikiem systemu) i jego tekstową aktualizacją (należy podkreślić, że syntagmę Schwarzenegger dla ubogich Dorota Kopczyńska zaliczyłaby do wyodrębnionej przez siebie kategorii frazeologizmów okazjonalnych, tzn. wyrażeń tworzonych doraźnie na podstawie inwariantnej struktury, por. Kopczyńska 2002: 31).

Ciągi: 8. i 9. zakwalifikowano natomiast do grupy frazemów, ponieważ zestawienia rewolucja seksualna i perła Bałtyku spełniają warunek odtwarzalności nakładany na reprodukty (w obserwowanym zbiorze tekstów połączenie musi zostać użyte w kontekście wtórnym co najmniej dwukrotnie, por. Dziamska-Lenart, Fliciński 2016: 12). Inwarianty służą więc m.in. do tworzenia frazemów. Autorzy nie zarezerwowali jednak nazwy dla okazjonalnych realizacji tekstowych modeli semantyczno-strukturalnych. Nazwę obejmującą swym zakresem m.in. okazjonalizmy zaproponował Wojciech Chlebda - wyrażenie pogoda dla kinomanów (przykład: 4.) jest frazemem aktualnym, tzn. tekstowym wariantem realizacyjnym zakodowanego w mózgu inwariantu mentalnego, czyli matrycy psychicznej (Chlebda 2005: 262). Posługiwanie się określeniami inwariant mentalny i matryca psychiczna może jednak narazić frazematykę na zarzut redukowania teorii frazeologicznej do teorii z zakresu psychologii (por. uwagi Tadeusza Zgółki dotyczące przedteoretycznego i teoretycznego stadium rozwoju dyscyplin humanistycznych, sformułowane w: Zgółka 1980: 21-46).

We frazeologii operacyjnej przyjmuje się, że realizacje tekstowe inwariantu (jednostki języka) są fraze ologi zma mi a ktualnymi (w niniejszej perspektywie pojęcia inwariant nie relatywizuje się do pojęć funkcjonujących w obrębie dyscyplin naukowych innych niż językoznawstwo). Termin ów zdaje sprawę z tego, że aktualizacja tekstowa frazeologizmu-schematu syntaktycznego jest - w przeciwieństwie do regularnych kon- 
strukcji składniowych - rezultantem nieswobodnej, tzn. obarczonej f u n kcją językową, operacji uzupełnienia pozycji syntaktycznych jednostki elementami należącymi do ściśle określonych klas o charakterystyce ogólnej (innymi słowy, frazeologizmy aktualne i konstrukcje składniowe są bytami o odmiennym statusie ontologicznym). Przydawka aktualny informuje o tym, że mamy do czynienia ze zjawiskiem tekstowym. Zaletą proponowanej nazwy jest to, że w jej zakres wchodzą zarówno ciągi tworzone okazjonalnie, jak i wyrażenia powtarzalne, odznaczające się statystyczną, ale nie: systemową, regularnością. Prezentowane tutaj stanowisko pozostaje przynajmniej częściowo kompatybilne z ustaleniami Sebastiana Żurowskiego - według badacza np. połączenia Paryż północy czy Jugosławia Kaukazu (wygenerowane przez jednostkę coś- ${ }_{i}$ czegos ${ }^{-}{ }_{j}$ 'coś ma się tak do $j$, jak $i$ do pewnej innej rzeczy') „można uważać za w jakimś stopniu »sfrazeologizowane«" (Żurowski 2013: 424-425). Z proporcjonalistycznego punktu widzenia wprowadzenie terminu frazeologizm aktualny jest konieczne, jeżeli chce się utrzymać w mocy przywołaną w szkicu diagnozę Anny Pajdzińskiej i Andrzeja Marii Lewickiego (mowa o tym, że inwariantem związku frazeologicznego może być schemat syntaktyczny). Twierdzenie, że struktura składniowa jest inwariantem (tzn. jednostką języka) związku frazeologicznego (tzn. jednostki języka), prowadzi do sprzeczności, ponieważ zakłada, iż do sfery langue należą: i inwariant, i jego realizacje, tj. związki frazeologiczne. Przyjmuję więc, że - na gruncie frazeologii operacyjnej - schemat syntaktyczny jest inwariantem frazeologizmów aktualnych, co jest zgodne z założeniem, iż zbiór jednostek języka tworzą tylko elementy już dalej niepodzielne ${ }^{10}$.

${ }^{10}$ Konieczne wydaje się odróżnienie metafory aktualnej (por. Bogusławski 1971) od frazeologizmu aktualnego. Ta pierwsza to „twórcze, spontaniczne użycie wyrażenia w odniesieniu, które nie jest dla niego właściwe [...]” (Bogusławski 1971: 120), co znaczy, że metafora aktualna: a) nie stanowi prostego zastosowania jednostki języka; b) nie ma przewidzianego przez system zakresu użycia (Bogusławski 1971: 115-116). Z kolei frazeologizm aktualny jest produktem standardowe go - wyznaczanego przez klasy substytucyjne niezamknięte - działania na narzędziu językowym (por. uwagi o narzędziowej konceptualizacji jednostek języka, pomieszczone w: Bogusławski 2008: 20-26). 


\section{Założenia frazeologii operacyjnej, czyli podsumowanie}

We frazeologii operacyjnej przyjmuje się tezę o prymacie materii dźwiękowej w języku (por. Bogusławski 1988: 170-184). Przedmiotem zainteresowania formułowanej teorii (wyrastającej z gramatyki operacyjnej Andrzeja Bogusławskiego, por. Bogusławski 1988) są wyłącznie związki frazeologiczne, których nietypowość (nieregularność funkcjonalna) ujawnia się na poziomie składniowym, tzn. na poziomie schematu syntaktycznego, i/lub we właściwościach suprasegmentalnych. Wynika z tego, że w obrębie charakteryzowanego paradygmatu zwroty typu ktoś ma kiełbie we tbie nie doczekają się opisu, ponieważ asumaryczność znaczeniową jednostki determinują elementy z płaszczyzny leksykalnej - metaforyczność wyrażenia jest efektem specyficznego uwikłania segmentów: kiełbie, we oraz łeb. Za usunięciem przywołanego związku z pola obserwacji frazeologii operacyjnej przemawia to, że: a) połączenie jest regularne składniowo, b) uzupełnienie pustego miejsca ktoś rzeczownikiem osobowym nie naruszy reguł łączliwości leksykalno-semantycznej. Narzędzi do satysfakcjonującej interpretacji takich idiomów dostarczają inne koncepcje frazeologiczne (por. np. zbiór sądów naukowych Stanisława Bąby poświęconych syntagmatyce frazeologiczno-leksykalnej, zamieszczonych w: Bąba 2009: 119-136).

Pojęciem nadrzędnym we frazeologii operacyjnej jest matryca frazeotwórcza - owo pojęcie stanowi hiponim określenia związek frazeologicz$n y$, a swoją nazwę zawdzięcza temu, że matryca generuje frazeologizmy aktualne ${ }^{11}$. Ekstensję wprowadzanego w tym akapicie terminu tworzą idiomy będące obiektem badań frazeologii operacyjnej. Oznacza to, że matryca frazeotwórcza jest typem związku frazeologicznego. Ścieżka od najwyższego hiperonimu przedstawia się więc następująco: jednostka języka $\rightarrow$ związek frazeologiczny $\rightarrow$ matryca frazeotwórcza.

Roboczo przyjmuję, że matryca frazeotwórcza to nieregularna funkcjonalnie jednostka języka w postaci częściowo zapełnionego leksykalnie lub pozbawionego wykładników segmentalnych schematu syntaktyczno-prozodycznego o stabilnej znaczeniowo treści, podstawowo przystosowanego do

11 Zestawienie matryca frazeotwórcza pojawiało się wcześniej m.in. w pracach: Fliciński 2015; Dziamska-Lenart, Fliciński 2016. W szkicu tym nadaję wskazanemu wyrażeniu definicję konstrukcyjną. 
różnowartościowej - w obrębie klas substytucyjnych niezamkniętych - aktualizacji leksykalno-zakresowej w tekstach oraz do aktualizacji prozodycznej tworzonych w ten sposób realizacji. Funkcja stałych miejsc otwartych schematu (czyli pozycji składniowych wymagających uzupełnienia komponentami leksykalnymi podczas aktu mowy): nie ogranicza się wyłącznie do przyjmowania wypełnień przewidzianych przez regularny, tzn. wyczerpujący znamiona symetrii funkcjonalnej, mechanizm łączliwości: składniowej i/lub leksykalno-semantycznej (wygenerowany układ tekstowy może - ale: nie musi! - być nieregularny na poziomie składni zewnętrznej, por. koncept składni wewnętrznej i zewnętrznej w: Lewicki 1983).

Wcześniej rozważałem inny kształt definicji: twierdziłem, że - gdy nie zostanie spełniony warunek wprowadzany przez zdanie rozpoczynające się od ,nie ogranicza się...” - funkcja stałych miejsc otwartych schematu polega na przyjmowaniu regularnych składniowo (składnia wewnętrzna) i leksykalno-semantycznie wypełnień, które na powierzchni współtworzą - z perspektywy składni zewnętrznej - nieregularną (np. całkowicie asyntaktyczną) całostkę. Zostałem zobligowany do tego, aby zmodyfikować brzmienie definiensa, ponieważ zebrane przeze mnie ciągi ,,podejrzewane o regularność" (np. $N_{\text {nom }}$ jak $N_{\text {nom }}$, por. ilustrację z SRiPP: 228-229: ...stodoła jak stodota, nic ciekawego) okazywały się nietypowe już na poziomie składni wewnętrznej (człony rzeczownikowe nie przyjmują określników). Preparowanie przykładów (np. $N_{\text {nom }}$ jak $N_{\text {nom }}$, por. 'ta gitara jak ta gitara - nie stroi 'o tej konkretnej gitarze wiadomo, że nie stroi'), w których rzeczowniki występowałyby np. w sąsiedztwie wykładników wyznaczoności (a utworzony w ten sposób frazeologizm aktualny nie mógłby wchodzić na wszystkie pozycje przewidziane dla fraz nominalnych), nie przyniosło oczekiwanych efektów. Być może opuszczony fragment zyska obowiązującą moc, np. wskutek dostrzeżenia przez lingwistę odpowiedniej jednostki języka albo w wyniku wyodrębnienia się w polszczyźnie określonej matrycy - frazeologię operacyjną interesuje przecież $L_{\text {prosp }}$, tzn. kod (język) wraz z jego przyszłymi możliwościami (Bogusławski 1988: 171-172).

Z obecnego kształtu definicji wynika, że właściwości prozodyczne matryc są ich przyrodzonymi właściwościami systemowymi. Jednostka może mieć regularną lekcję prozodyczną lub odznaczać się idiosynkratycznym konturem intonacyjnym. Taki kontur ma np. matryca $\| \mathrm{w} \mid$ |w $\downarrow \|$, która musi zostać zrealizowana w ramach jednej frazy fonologicznej i która generuje - 
jako odpowiedzi na pytanie o rozstrzygnięcie - frazeologizmy aktualne typu: przyjdę, przyjdę czy śpiewaj, śpiewaj (znaczniki wykładników prozodycznych: || - granica frazy fonologicznej; | - granica taktu; " - przycisk zdaniowy kontrastywny; $\downarrow$ - kadencja; opis konturu - jednego z dwu przypisanych tej jednostce - pochodzi z: Dobaczewski 2018: 109-127). Matryca ta realizuje się tekstowo poprzez frazeologizmy aktualne naruszające fundamentalną dla składni regułę niełączenia elementów tożsamych, identycznych (Dobaczewski 2018: 47-54).

Definicja implikuje wniosek, że matrycą frazeotwórczą może być wyłącznie schemat aktualizowany w postaci przynajmniej dwuwyrazowego połączenia (jednosegmentowe idiomy pozostają więc przedmiotem zainteresowania teorii referowanych m.in. w: Bogusławski, Garnysz-Kozłowska 1979; Bogusławski 1989; Chlebda 2010). Kandydatami do tak pojmowanych matryc są - nienotowane wcześniej (przynajmniej w takiej formie) - operacje: $k t o s_{-i}$ po $c z y m s_{-j}$ 'ktoś $i$, kto tak jak osoba, o której mowa, należy do społeczności symbolizowanej przezj' (por. kolega po piórze, koleżanka po batucie, kumpel po szalu; por. Dziamska-Lenart 1993); coś ${ }_{-j}$ jakieśs 'odpowiednik $j$ zrobiony ze składnika $i$ ' (por.: boczek roślinny, parówki sojowe, pasztet marchewkowy); czyjśs ${ }_{-i} /$ czyjeśs ${ }_{-i} k t o s_{-j} / \cos _{-j}$ 'należący do społeczności $i$ odpowiednik j' (por.: polski Jim Carrey, ślaski Wernyhora, szczeciński Jankowski, działdowskie Wembley, nasze K2) oraz ileśs na ileśs (wariantywnie: ileśs / $_{-i} e_{-j}$ ) 'mówiący przyznaje temu, o czym mowa, liczbę punktów $i$ w skali liczącej $j$ punktów' (por. ...jeżeli chodzi o smak, to daję 5 na 5; ...jego ostatniemu filmowi dałem 7/10). Podkreślam, że wyrażenie matryca frazeotwórcza nie jest synonimem terminu operacja - zbiór matryc zasilają także schematy zawierające KSS-y, np. jednostka ktoś gryzie coś 'ktoś walczy z bardzo dużą determinacją o satysfakcjonujące wyniki w sporcie' (por..... w pólfinale będziemy gryźć żużel; gryźliśmy lód, ale mistrzami Polski zostali hokeiści z Jastrzębia). Zakładam, że czasownik gryźć nie jest tutaj samodzielnym nośnikiem wartości znaczeniowej - sens zakodowano w matrycy, nie: w KSS-ie. Pierwsze miejsce otwarte uzupełnia się regularnym leksykalno-semantycznie wyrażeniem odnoszącym się do osoby lub grupy osób, drugie - należy wypełnić elementem reprezentującym klasę o charakterystyce: 'rzeczownik nazywający nawierzchnię, na której uprawia się sport'. Tak utworzony frazeologizm aktualny łamie zasady regularnej łączliwości leksykalno-semantycznej. 
$\mathrm{Na}$ zakończenie tych wstępnych rozważań wskażę grupę elementów, które znajdują się poza obszarem zainteresowania frazeologii operacyjnej. W SRiPP zarejestrowano kandydata do miana operacji repetycyjnej $N_{\text {nom }}$ $w N_{a c c}$ 'to, o czym mowa w zdaniu, dzieje się w taki sposób, że dwa lub więcej obiektów, o których mowa, znajdują się naprzeciwko siebie' (por. ...z Andrzejem siedziałem później cela w celę, SRiPP: 254-255). Porządek linearny wyrażenia cela $w$ celę odwzorowuje porządek obowiązujący w rzeczywistości pozajęzykowej, tzn. temu, że dwie cele znajdują się vis-à-vis, odpowiada to, że na linii tekstu formy gramatyczne leksemu cela występują również naprzeciw siebie. Rozpoznanie motywacji ikonicznej wyrażenia dyskwalifikuje je jako obiekt badań frazeologii operacyjnej (przyjmuję, że element $x$ $y$ będzie matrycą frazeotwórczą dopóty, dopóki jego ikoniczność nie zostanie rozpoznana). Mimo że we frazeologii operacyjnej porzuca się ideę o absolutnej arbitralności znaków językowych - są one przecież umotywowane w stosunku do innych znaków występujących w systemie (por. Zgółka 1980: 76) - to rozpoznana ikoniczność ciągu $x y$ jest argumentem przeciwko uznaniu go za matrycę frazeotwórczą. Założenie to harmonizuje z przywołaną w szkicu tezą Andrzeja Marii Lewickiego, zgodnie z którą prace językoznawcze wyodrębniają związki frazeologiczne ${ }^{12}$.

12 Wprowadzenie frazeologii operacyjnej budzi szereg wątpliwości. Najpoważniejszą z nich zwerbalizuję następująco: czy powołanie do życia charakteryzowanej koncepcji przyniesie coś więcej ponad to, co można osiągnąć już dzięki gramatyce operacyjnej? Odpowiedź jest twierdząca. Frazeologia operacyjna stanowi część gramatyki operacyjnej, dlatego też nie wykracza poza wyznaczone przez nią granice procedury badawczej. Jednakże referowany tu paradygmat frazeologii teoretycznej wyodrębnia przedmiot zainteresowania, $\mathrm{tj}$. matryce frazeotwórcze i frazeologizmy aktualne, za pomocą kryteriów, które pozwalają - w nieco inny sposób niż w standardowej interpretacji gramatyki Andrzeja Bogusławskiego - opisać status ontologiczny bytów językowych, będących obiektem badań paradygmatu. We frazeologii operacyjnej obowiązuje podział na KSS-y i operacje, ale - ze względu na specyfikę przedmiotu obserwacji - uznaje się go za sekundarny (matrycami są przecież jednostki zawierające KSS-y, jak i jednostki ich pozbawione). Innymi słowy, kształtująca się koncepcja poszukuje relewantnych loci communes KSS-ów i operacji. Za cenne uwagi, dzięki którym powstały passusy w przypisach: 10 i 12., serdecznie dziękuję Recenzentom. 


\section{Bibliografia}

BAŃKo M., 2001, Z pogranicza leksykografii i językoznawstwa: studia o słowniku jednojęzycznym, Warszawa: Wydział Polonistyki UW.

BąBA S., 2009, Frazeologia polska: studia i szkice, P. Fliciński, K. Skibski (red.), Poznań: Wydawnictwo „Poznańskie Studia Polonistyczne”.

BednareK A., Grochowski M., 1993, Zadania z semantyki językoznawczej, Toruń: Wydawnictwo UMK.

Bobrowski I., 2005, Składniowy model polszczyzny, Kraków: Wydawnictwo Lexis.

BogusŁawski A., 1971, O metaforze, Pamiętnik Literacki, z. 4, s. 113-126.

BogusŁawski A., 1976, O zasadach rejestracji jednostek języka, Poradnik Językowy, z. 8, s. 356-364.

BogusŁawski A., 1987, Obiekty leksykograficzne a jednostki języka, w: Z. Saloni (red.), Studia z polskiej leksykografii współczesnej, t. 2, Białystok: Dział Wydawnictw Filii UW, s. 13-34.

BogusŁawski A., 1988, Preliminaria gramatyki operacyjnej, Polonica 13, s. 163-222.

BogusŁawski A., 1989, Uwagi o pracy nad frazeologią, w: Z. Saloni (red.), Studia z polskiej leksykografii wspótczesnej, t. 3, Białystok: Dział Wydawnictw Filii UW, s. 13-30.

BogusŁawski A., 1993, O proporcjonalności w języku i jej warunkach, w: J. Sambor, J. Linde-Usiekniewicz, R. Huszcza (red.), Językoznawstwo diachroniczne i synchroniczne, Warszawa: Wydawnictwo UW, s. 59-76.

BogusŁawski A., 1996, Jeszcze o delimitacji bilateralnych wielkości językowych, w: E. Rzetelska-Feleszko (red.), Symbolae slavisticae: dedykowane pani profesor Hannie Popowskiej-Taborskiej, Warszawa: Slawistyczny Ośrodek Wydawniczy, s. 47-56.

BogusŁawski A., 2008, Semantyka, pragmatyka. Leksykografa głos demarkacyjny, Warszawa: Wydawnictwo „Takt”.

BogusŁawski A., Garnysz-KozŁowska T., 1979, Addenda do frazeologii polskiej: zeszyt wstepny, Carbondale-Edmonton: Linguistic Research.

Chlebda W., 2003, Elementy frazematyki: wprowadzenie do frazeologii nadawcy, Łask: Oficyna Wydawnicza LEKSEM.

ChlebDa W., 2005, Szkice o skrzydlatych stowach: interpretacje lingwistyczne, Opole: Wydawnictwo Uniwersytetu Opolskiego.

Chlebda W., 2010, Skrzydlate słowa a frazeologia, w: S. Bąba, K. Skibski, M. Szczyszek (red.), Perspektywy wspótczesnej frazeologii polskiej. Teoria. Zagadnienia ogólne, Poznań: Wydawnictwo Naukowe UAM, s. 9-20. 
DANiELEwiczowa M., 2010, Schematy składniowe - podstawowe kwestie metodologiczne, Poradnik Językowy, z. 3, s. 5-27.

Davidson D., 2005, Truth, Language, and History: Philosophical Essays Volume 5, Oxford: Clarendon Press.

DobaCZewsKi A., 2018, Powtórzenie jako zjawisko tekstowe i systemowe: repetycje, reduplikacje i quasi-tautologie w języku polskim, Toruń: Wydawnictwo Naukowe Uniwersytetu Mikołaja Kopernika.

Dziamska-Lenart G., 1993, Kolega po piórze, Głos Wielkopolski, nr 72, s. 23.

Dziamska-Lenart G., FliciŃski P., 2016, Nowa frazeologia publicystyczna, w: K. Skibski, A. Piotrowicz, M. Witaszek-Samborska (red.), Kultura komunikacji w językach stowiańskich: co nas łączy, co różni, co dziwi, Poznań: Wydawnictwo Poznańskiego Towarzystwa Przyjaciół Nauk: Wydział Filologii Polskiej i Klasycznej Uniwersytetu im. Adama Mickiewicza, s. 11-25.

Fish S. E., 2002, Interpretacja, retoryka, polityka: eseje wybrane, A. Szahaj (red.) (tłum. K. Abriszewski, A. Derra-Włochowicz, M. Glasenapp-Konkol, A. Grzeliński, M. Kilanowski, A. Lenartowicz, M. Smoczyński, A. Szahaj), Kraków: Universitas.

FLICIŃSKI P., 2008, Co po „Psach” zostało? Refleksje frazeografa o niefilmowej przestrzeni współczesnej polszczyzny, Images 11-12, s. 189-197.

FLICIŃSKI P., 2015, Migracja stylistyczna w zakresie frazeologii czy zapożyczenie wewnętrzne?, w: B. Afeltowicz, E. Pajewska (red.), Dyskursy trzeciego tysiaclecia III, Szczecin: Volumina.pl Daniel Krzanowski, s. 47-59.

Frege G., 1977, Pisma semantyczne (tłum. B. Wolniewicz), Warszawa: Państwowe Wydawnictwo Naukowe.

Grochowski M., 1982, Zarys leksykologii i leksykografii: zagadnienia synchroniczne, Toruń: UMK.

Grochowski M., 1993, Konwencje semantyczne a definiowanie wyrażeń językowych, Warszawa: Zakład Semiotyki Logicznej Uniwersytetu Warszawskiego „Znak - Język - Rzeczywistość”: Polskie Towarzystwo Semiotyczne.

GrzegorczyKowa R., 2012, Wyktady z polskiej składni, Warszawa: Wydawnictwo Naukowe PWN.

JANUSZKIEWICZ M., 2012, Wczytywanie (się) w tekst. O interpretacji transakcyjnej, Teksty Drugie, z. 1-2, s. 74-86.

JANuszkiewicz M., 2013, O interpretacji, Przestrzenie Teorii 20, s. 219-233.

JEZIERSKa B., 2016, Frazeologizmy w polskich przekładach współczesnej prozy francuskiej, Poznań: Wydawnictwo „Poznańskie Studia Polonistyczne”.

KoPCZYŃsKa D., 2002, Metafory nazwiskowe w konstrukcjach z pogranicza frazeologii i składni, Poradnik Językowy, z. 6, s. 30-42.

KoseK I., 2011, Wariantywność zwrotów frazeologicznych a granice jednostki leksykalnej, w: P. Fliciński (red.), Perspektywy współczesnej frazeologii polskiej. Wa- 
riantywność we frazeologii, Poznań: Wydawnictwo Naukowe Uniwersytetu im. Adama Mickiewicza, s. 9-22.

LEWICKI A. M., 1976, Wprowadzenie do frazeologii syntaktycznej: teoria zwrotu frazeologicznego, Katowice: UŚ.

Lewicki A. M., 1983, Składnia związków frazeologicznych, Biuletyn PTJ, t. 40, s. $75-83$.

LEWICKI A. M., 2003, Studia z teorii frazeologii, Łask: Oficyna Wydawnicza LEKSEM.

LiBEREK J., 1999, Skrzydlate słowa w perspektywie frazeologicznej. (Sprawozdanie z posiedzenia Komisji Frazeologicznej Komitetu Językoznawstwa PAN, Warszawa, 6 listopada 1998 roku), Poradnik Językowy, z. 4, s. 41-51.

NowaK T., 2013, Od przesłanki do konkluzji: polskie czasowniki wnioskowania, Katowice: Wydawnictwo Uniwersytetu Śląskiego.

PAJdzIŃSKA A., 1982, Szeregi wariantów a mechanizmy łączliwości frazeologicznej, w: A. M. Lewicki (red.), Stałość i zmienność związków frazeologicznych, Lublin: UMCS, s. 55-67.

PJZ: BogusŁawski A., WaWrzyńczyk J., 1993, Polszczyzna, jaka znamy: nowa sonda słownikowa, Warszawa: Uniwersytet Warszawski.

Rorty R., 1996, Przygodność, ironia i solidarność (tłum. W. J. Popowski), Warszawa: Wydawnictwo SPACJA.

RoRTY R., 1999, Obiektywność, relatywizm i prawda (tłum. J. Margański), Warszawa: Fundacja Aletheia.

RosAlSKA P., 2011, Krok po kroku, krok za krokiem, krok w krok - konstrukcje składniowe czy jednostki języka?, Linguistica Copernicana 6 (2), s. 149-160.

SAlONi Z., ŚwidZIŃSKi M., 2001, Składnia współczesnego języka polskiego, Warszawa: Wydawnictwo Naukowe PWN.

SkiBSKi K., 2017, Poezja jako iteratura: relacje między elementami języka poetyckiego w wierszu wolnym, Poznań: Wydawnictwo Naukowe UAM.

SKorupKa S., 1967, Słownik frazeologiczny języka polskiego, t. 1, Warszawa: Wiedza Powszechna.

SPP: Anusiewicz J., SkawiŃski J., 1996, Słownik polszczyzny potocznej, Warszawa-Wrocław: Wydawnictwo Naukowe PWN.

SRIPP: Dobaczewski A., Sobotka P., Żurowski S., 2018, Słownik reduplikacji i powtórzeń polskich: od zleksykalizowanych podwojeń do regularnych uktadów repetycyjnych, Torun: Wydawnictwo Naukowe Uniwersytetu Mikołaja Kopernika.

Stefanowitsch A., 2007, Wortwiederholung im Englischen und Deutschen: eine korpuslinguistische Annäherung, w: A. Amman, A. Urdze (red.), Wiederholung, Parallelismus, Reduplikation. Strategien der multiplen Strukturanwendung, Bochum: Universitätsverlag Brockmeyer, s. 29-45. 
SWFP: BĄBA S., LiBEREK J., 2001, Stownik frazeologiczny współczesnej polszczyzny, Warszawa: Wydawnictwo Naukowe PWN.

Szahau A., 2012, Ironia i miłość: neopragmatyzm Richarda Rorty'ego w kontekście sporu o postmodernizm, Toruń: Wydawnictwo Naukowe Uniwersytetu Mikołaja Kopernika.

Szerszunowicz J., 2012, Connotations and Schemata in Phraseology (on the example of the Polish unit druga Japonia), w: A. Inoue, T. Kanzaki (red.), Aspects of English Studies in the 21 Century. Linguistic and Cultural, Tokyo: Kaitakusha, s. 398-427.

Szerszunowicz J., Vidović Bolt I., 2019, Konwencjonalne peryfrazy zastępujące antroponimy w ujęciu kontrastywnym (na przykładzie polskich wyrażeń omownych i ich chorwackich odpowiedników), Poznańskie Studia Slawistyczne 15, s. 287-304.

VPA: - Boguslawski A., Danielewiczowa M., 2005, Verba polona abscondita: sonda stownikowa III, Warszawa: Elma Books.

Wierzbicka A., 1987, Boys Will Be Boys: 'Radical Semantics' vs. 'Radical Pragmatics', Language 63 (1), s. 95-114.

WSF: FLICIŃSKi P., 2012, Wielki stownik frazeologiczny, Poznań: Wydawnictwo IBIS.

WSJP PAN: Wielki stownik języka polskiego PAN, 2007-, P. Żmigrodzki (red.), Kraków: Instytut Języka Polskiego PAN, [online:] https://wsjp.pl [29.05.2021].

Zawadowski L., 1966, Lingwistyczna teoria języka, Warszawa: Państwowe Wydawnictwo Naukowe.

ZGóŁKa T., 1980, Język, kompetencja, gramatyka: studium z metodologii lingwisty$k i$, Poznań-Warszawa: Państwowe Wydawnictwo Naukowe.

ŻABowsKa M., 2017, Niedookreślenie, dekonkretyzacja i zmienne językowe-o quasi-tautologicznych układach typu ten $i$ ten, to $i$ to, tak a tak, LingVaria 12 (23), s. $115-129$.

ŻUrowski S., 2013, Gdzie szukać w słownikach nieleksykalnych jednostek języka?, Prace Filologiczne 64 (1), s. 421-430.

Мокиенко В. М., 1980, Славянская фразеология, Москва: Высшая школа.

ШулЕжкова С. Г., 2002, Крылатые выражения русского языка, их источники и развитие, Москва: Издательский центр „Азбуковник”. 


\section{Sentence pattern as an idiom - prolegomena to operational phraseology ( s u m mary)}

The aim of this article is to provide a preliminary characterisation of operational phraseology, the shape of which emerges from Andrzej Bogusławski's operational grammar. The reflections in the first subsection of the article, based on the American neopragmatist philosophy, concern the ontological status of idioms. The next two parts of the text are devoted to the terms: sentence pattern and present phraseologism. The second of these terms denotes the textual realisation of a phraseological compound, i.e. an element of the langue sphere. In the last part of the article, the author defines (from a proportionalist point of view) the proper research object of the discussed paradigm of theoretical phraseology - it is a linguistic entity (phraseologism, more precisely: phraseologism-generating matrix) manifesting irregularity on the sentence pattern level and/or on the suprasegmental level.

Ke y w ord s: operational phraseology; operational grammar; phraseologism-generating matrix; language unit 
